\title{
Theology and development: Taking personal responsibility for community development
}

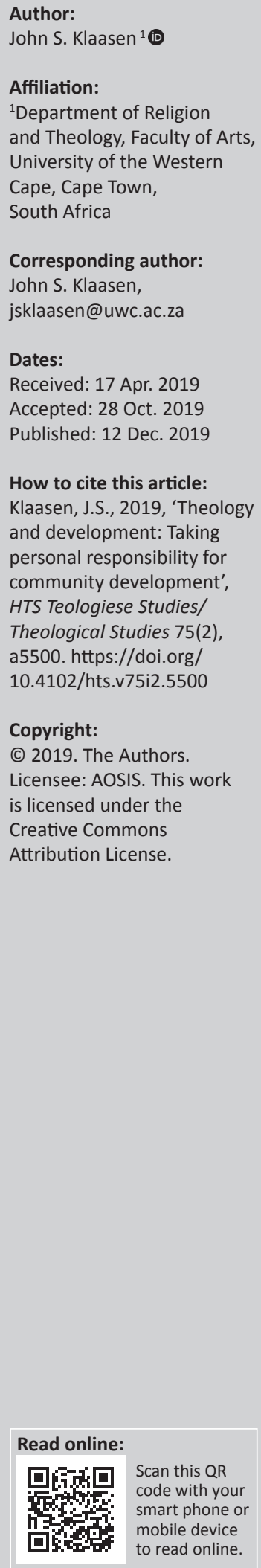

\section{Author:}

Affiliation

${ }^{1}$ Department of Religion University of the Western

Cape, Cape Town

rresponding author:

John S. Klaasen,

Dates:

Received: 17 Apr. 2019

Accepted: 28 Oct. 2019

How to cite this article:

Klaasen, J.S., 2019, 'Theology

and development: Taking

community development',

HTS Teologiese Studies/

Copyright:

C 2019. The Authors

is licensed under the

Creative Commons
This article is part of an international research group, CODE, to address the inadequacies of the dominant community development theories and models. This is an attempt to deal with personal responsibility for development from a theological perspective. The limitations of the modernisation theory and secular theories such as Sen's expansion of choices are pointed out as hegemonic or amorphous. Personhood as the root of personal responsibility forms the point of convergence for perceived opposites such as being and doing, individual and community, and receiver and giver. Important themes such as reciprocity, perichoresis, creation and vocation as found in relational theology form the basis of a contribution by theology to community development.

Keywords: Community development; Perichoresis; Personhood; Creation; Theology; Relational responsibility.

\section{Introduction}

Community development has come under scrutiny from both the so-called hard sciences and soft sciences. Economic developmental efforts and a one-way development process of the modernisation theory are evident in the ecumenical church discourse of the 1960s and 1970s. However, a paradigm shift from commodity-oriented development to value-based development took place in the 1970s and 1980s. Korten's four-stage development theory is a classical attempt to include the resources of particular communities in the development process. The typical issue at stake is not limited to economic and technological advancement but how this advancement takes place. CODE ${ }^{1,2}$ (Use Your Talents, CABLE and Seeking Conviviality) somewhat addresses the issue of agency and values.

This article is an attempt to add to the shift in the development discourse from giver-receiver to a more inclusive participatory community development paradigm. My contribution will deal with personal responsibility within the context of theological anthropology for community development. How do the theological understandings of what it means to be a person contribute to community development? Whilst this is a theological contribution, I will critically engage with the valuable contributions from other sciences that are represented by influential scholars such as the Nobel Laureate and economist Amartya Sen and David Korten. The former's capability approach of increasing choice and the latter's planned social change to promote community development in a larger social context and then within specific economic growth can be viewed against what guarantee is there that the person will take responsibility for development. To contribute to community development, personal responsibility will take cognisance of the divergence of being and doing, individual and community, and receiver and giver, which is found in personhood. The level and degree of interaction between these divergent phenomena influence effective and sustainable community development. I will refer to the interaction as 'creative tension'.

Personhood does not refer to personal development that is commonly understood within psychological development as maturity, nor is it about physical development that is closely related to biology and the development of the physical body. Personhood is also not restricted to identity and social construction of which culture and religion are important phenomena. Personhood lies within the entanglement of doing and being as commonly found in theology and ethics. Personhood will also be contrasted and compared with person and individual.

1.CODE is an international research group that was established as a result of the limitations in diaconal engagement by church communities. The limitations that were identified include the diversity of society and the need for interfaith and intercultural diaconal collaboration, the inability of development models to sustain development efforts, the need to include local congregations and restructuring of social welfare and social security according to neo-liberal principles (taken from the Summary Report of the CODE Forum: Community, Participation and Power, Oslo, Norway, 19-20 October, 2017, by Prof. Stephanie Dietrich). 


\section{Community development}

The Collins English Dictionary (n.d.) defines development as a metaphor with roots in the French 'dêveloppement' which indicates the unfolding of property, bringing to the fore the invisible potential. It is also the process of adding layers so that 'cross-folding would add layers of complexity and capacity' (Conradie 2016).

Two criticisms against the use of the term 'development' have been its amorphous nature as a result of the many ways it has been used in various contexts and by diverse agents. The many adjectives such as human, sustainable, economic, social and even political have complicated the identification of a particular kind or character of the term 'development'. The danger of the amorphous term 'development' is illustrated in the 2010 Human Development Report of the Oxford Poverty and Human Development Initiative (Alkire 2010). According to Klaasen (2013):

Whilst the 1990 report consists of the clarifications of concepts, the 1991 to 1993 reports reflect the importance of human capital in the process. Between 1994-2010, human security, gender, economic growth, poverty, consumption, globalization, human rights, technology, democracy, millennium development goals, cultural liberty, international cooperation, water, climate change and migration, the dimensions of development, are firmly entrenched as the focus points. (p.184)

On the other hand, development has also taken on the position of hegemony and resulted in the domination of the 'developing' by the 'developed'. A typical example according to Springett and Redclift (2015) would be:

\begin{abstract}
International fora on environment and sustainable development from the Stockholm Conference in 1972 to the UNCSD (Rio+20) in 2012, as well as key international Strategies and Reports, have tended to legitimate the North's power over and domination of the construct, while appearing to be seeking 'solutions'.... The fact that collusion between these dominant forces governs the outcomes of international debates on environment and sustainable development has been difficult to overlook. The voices of non-governmental organisations (NGOs) and the South have gradually been heard after much struggle, though without achieving equal power. (p. 7)
\end{abstract}

Hegemony naturally favours universalism against relativism and similar over dissimilar. In other words, development has more to do with making difference into sameness and discarding the particular for the universal. What is good for the one is good for the other. Bosch (1991:433-434) rightly asserts that the limitation of the modernisation theory was the attempt to replicate the development of the North in the South.

According to Bosch, this secular notion of development also made inroads into the church. To this end, the two most significant gatherings of the World Council of Churches after the First and Second World Wars epitomised the NorthSouth development process (Bosch 1991):
Governments of the First and Second Worlds were going to contribute to the solution of the problem of Third-World poverty by pouring their resources into ambitious development projects. Hurriedly, Western churches and mission agencies got onto the bandwagon as well. (p. 433)

The 1966 Geneva Church and Society Conference and 1968 Uppsala World Council Assembly closely aligned with the hegemony of the modernisation theory. The focus of development was a narrow view of economic and technological development of the South in alignment with Western countries.

To some extent, development within the South African context was used amorphously during the 1960s with the notion of 'separate development'. The South African government used development to separate communities along lines of race and colour to promote the idea of developing separately according to skin colour classification. In post-apartheid South Africa, development has taken hegemonic form by either co-opting or later discarding the role of the church and non-government organisations from the development discourse. The South African Council of Churches experienced governmental development efforts as both amorphous and hegemonic.

Community within the African discourse is commonly described by the term Ubuntu. Ubuntu is usually used in a way to contrast individualism and encapsulates some of the core elements of what is meant by community. Eze (2010) describes Ubuntu as follows:

A person is a person through other people strikes an affirmation of one's humanity through recognition of an 'other' in his or her uniqueness and difference. It is a demand for a creative inter-subjective formation in which the 'other' becomes a mirror (but only a mirror) for my subjectivity. This idealism suggests to us that humanity in not embedded in my person solely as an individual, my humanity is co-substantively bestowed upon the other and me. Humanity is a quality we owe to each other. (pp. 190-191)

This notion of community denigrates the individual to merely be a means to an end. The community is typically regarded as the norm for what it means to a person. This dominant notion of what it means to be person is steeply situated in influential African scholarship such as that of Mbiti and Menkiti.

The African philosopher Gyekye is more sceptical of the uncritical acceptance of Ubuntu as an equivalent for community. Community, according to Gyekye, is best described as 'moderate community'. In moderate community, the quality of the relationships amongst the individuals is different from that of the Ubuntu of Eze. Within this notion of community, the individual has greater significance and importance than in Eze's Ubuntu. Common values, individuality, social commitments and responsibilities to oneself are as important as the well-being of the community (Gyekye 1997:76).

From an African-Christian perspective, the tension between individualism and communitarianism is demonstrated in 
Tutu's theological formulation of Ubuntu community. The community is defined as interdependence between individuals in a state of vulnerability. The extent and nature of the relationship between individuals nurture the humanity of each other. Battle (1997) asserts the following:

[Tutu] stresses the Christian definition of relationship, as opposed to other social forms of communalism, to define Ubuntu. Influenced deeply by Anglican spirituality, Tutu is able to overcome African philosophy's tendency to go to the opposite extreme of discounting individuals for the sake of community. For him, being properly related in a theological Ubuntu does not denigrate individuality. Instead it builds an interdependent community. (p. 42)

Self-determination is denied, as in the notion adopted by Menkiti, but the individual is not above the community, as in Gyekye's notion. Tutu's notion of community transcends the normativity of reason, opportunities and choices (Klaasen 2017):

It comes through relationships with other persons in an open, trustworthy and honest environment. The self is not completely autonomous, but in its vulnerability penetrates the availability of choices and becomes an active forming and transforming agent. (n.p.)

\section{Tutu (2004) claims:}

We are stewards of all of this ... The dominion we were given in Genesis 1:26 was so that we should rule as God's viceroys, doing it as God would-caring, gently, not harshly and exploitatively, with a deep reverence, for all is ultimately holy ground and we should figuratively take off our shoes for it all has the potential to be 'theophanic' to reveal the divine. (pp. 28-29)

These kinds of creative relationships are made possible through transcendence of the self and the community. Relationship of an interdependent nature is as important for the self (self-concern, moral conscience, and ways of relating to their attitudes and actions) as it is for 'the other' (care, compassion, love and trust). This is not a reference to the other in a subordinate manner, but as a constructing other that is both dependent and independent. (Klaasen 2017:37)

Community development is about the interdependence of the meaning of the two terms. Community is the fluid substantive nature of the persons as a solid interactive organism. By organism is meant a 'complex structure of interdependent and subordinate elements whose relations and properties are largely determined by their function in the whole' (Merriam Webster Dictionary n.d.:n.p.). Community development is about cultivating and nurturing the potentially transforming agency. It is a process of movement towards transformation of form, forming and formation. It is a process of mutual and reciprocal growth towards our God-given humanity. It is about transcending the solid boundaries that divide by domination and separation. Community development starts with the acceptance that every person and community deserves the symbolic taking off of our shoes when entering the holy ground of the constructive other.

The two terms 'community' and 'development' converge at the point of creative tension. The individual has a role to play in the growth of the community by the very nature of the relationship between the persons within the community. The substance of the relationship unlocks the complexity and capability of the growth processes.

The answer to 'who we are' contributes to the complexity and capability. Identity is confined by social constructionism and limits the potential and flexibility of the person to social constructs and variables such as language, beliefs, religion, symbols and metaphors. Whilst social phenomena are significant to identity, personhood goes beyond being and notions of being. Personhood, from a Christian anthropological perspective, includes being and doing.

The individual and community are not regarded as antagonistic or different in the sense that they relate solely as independent variables, but their relationship takes place within the context of open-endedness and fluidity. There is more overlapping, transversality and to-and-from movement than the moderate community of Gyekye and the antagonism of Eze.

The complexity of the marginalised (receiver) and centre (giver) is not defined as an insurmountable distance but as potential additions to capability and capacity. Whilst the marginalised is not discarded as the space and face of insignificant for community development, the complexity that personal responsibility brings to community development reinterprets the space and face of the marginalised as greater significant factors for transformative community development.

These perceived opposites or negative dualisms can contribute to community development when their interaction is viewed as creative tension instead of hegemonic or amorphous. The two perceived opposites, such as individual and community, marginalised and centre, and giver and receiver, converge at personhood. It is not the one above the other, but both interact with an attitude of nurture and formation.

\section{Personhood}

The idea of personhood in African moral thought was first used by Ifeanyi Menkiti, a Nigerian philosopher, as persons who lead morally virtuous lives (Molefe 2017:1). Menkiti's notion of personhood is an attempt to differentiate the Western notion of person as locked within one specific quality. The Western normative quality for person is reason and is built on the influential ideology of Descartes who asserts that an individual is an individual because of the ability to reason. According to Menkiti, personhood is about the kind of life one lives. Menkiti also asserts that personhood is not inherent at birth but acquired over time within a community.

Molefe (2017) identifies three entangled, yet differentiated forms of personhood in Menkiti's notion. Firstly:

Menkiti....tells us that self-identity is possible only by reference to these collective (cultural) facts. In other words, Menkiti makes claims that individuals come to form their personal identities through socialization. And, in this process of identity formation, he insists that the community or social relationships are decisive. (Molefe 2017:3) 
Secondly, Menkiti aligns his notion of person with John Rawls' principle of the initial situation that implies that individuals have an intrinsic moral status that presumes personhood. In other words, persons have personhood not because of what they can do but because of the capacity or property that is essential for personhood (Molefe 2017:4). Thirdly, agent-centred persons are those whose moral conduct is outstanding in the community. At this point, Menkiti claims that personhood is something to be obtained. It is not inherent, but some persons can be without personhood at some stage of their life (Molefe 2017:4-5).

Within the dominant African notions of personhood, there has been both convergence and divergence of individual and community. The notions of Menkiti, Mbiti and Molefe put the individual under the dominance of the community. The individual's personhood is nurtured in the community, and unless the individual reaches certain moral status, he or she is denied personhood. Gyekye, on the other hand, goes to the other extreme by giving the individual such autonomy that the community has a moderate role in the personhood of individuals. Personhood is embedded in the nature of the relationship that the individual has with the community. Majeed asserts that Gyekye differs from Menkiti on two fundamental points: Firstly, the person has the capacity to be moral without outside forces such as the community, and secondly, rationality is normative for personhood. Majeed (2017:38) rejects 'processual' acquisition of personhood.

These two dominant notions of personhood in the African tradition raise critical points for community development. Is community development a right or duty? In the latter notion of Gyekye, personhood is ontological and therefore right takes precedence over duty. On the other hand, Menkiti's agent-centred personhood makes duty the means of community development (Molefe 2017):

To talk of rights is to talk of entitlements that engender duties to a right-holder (Donnely 2009). Rights as entitlements are prior and distinct from duties (Feinberg 1970). To have a right is to be empowered to make claims, assertions and demands that one's duties be fulfilled (Feinberg 1970). Thus, the direction of duties engendered by rights is right-holders directed. (p. 11)

Duty, on the other hand, refers to (Molefe 2017):

The duty for one to realise their true humanity takes central stage in African moral thought and this duty is essentially connected to promotion of the well-being of other human beings. (p. 11)

\section{Theology}

John de Gruchy describes a common humanity by making a distinction between individual, persons and human. Firstly, the individual is typically associated with the Enlightenment project's aim to place the individual at the centre of the world. The individual is characterised by autonomy, reason, choice and individual freedom. It is almost in protest against the monarchical, authoritarian and totalitarian forces of the pre-Enlightenment era. The individual is best described as the 'rational economic man' (Rawls) with attributes such as disembodied, autonomy and independence. Such a notion of personhood links to personal responsibility but human history attests to the gross human rights violations and genocides that have taken place over the last few decades in the quest for control. Secondly, personal identity, on the other hand, relates to the psychological and physiological development from childhood to adulthood. The person is constructed from birth to teens and then middle-age to old age. This process of development is influenced by specific phenomena such as gender, bodies, sexuality and culture. The personal is also interpersonal. To be human is about having some things in common. Despite the diversity of human qualities, love, for example, is common to all human beings and bridges the gap of diversity (De Gruchy 2006:42-46).

Personhood contrasts with individual in the degree of autonomy, the neglect of the role of tradition and the disconnectedness of the individual and the community. Personhood also differs from personal identity in so far as personhood is a relational construct. Whilst tradition and outside phenomena influence the exercise of personhood, it does not determine personhood. Personhood differs from humanness because of its complexity and capability within which diversity and difference are connected. This article recognises personhood as a complex state of being inherent in human beings.

The late Steve De Gruchy (son of John de Gruchy) questioned the notion of nurturing personhood by confronting Maluleke's notion of African agency. Quoting Maluleke, De Gruchy (2015) states:

I suggest that we are being called to a humble but careful observance of the struggles of Africans to be agents against great odds....Africans have always been agents, never 'simply victims, wallowing in self-pity', they have always exercised their agency in struggles for survival and integrity. However their agency has not always been recognised let alone nurtured. (p. 68)

De Gruchy (2015:68-69) does not direct our attention to the universality of agency but notes that the church community nurtures and enhances the agency of the poor. He qualifies the agency of the poor by moving beyond the focus of identity to agency.

De Gruchy (2015) provides further theological substantiations by re-interpreting the two creation stories:

It is important to recognise that in both creation accounts from which the affirmation of identity is traditionally drawn, the truth of being made in the image of God (Genesis 1:27) of being filled with God's own breath of life (Genesis 2:7) is immediately coupled with the theme of vocation, the calling to be responsible actors in this world newly created by God (Genesis 1:28, 2:15). This understanding of vocation is at the heart of the theological understanding of labour as a constitutive part of what it means to be human, in the use of our gifts and talents to be co-workers with God in the world. (p. 70) 
The being (created) and doing (vocation) challenges the respective antagonistic perceptions of African personhood adopted by Menkiti and Gyekye. For Steve de Gruchy, being alone is not enough embodiment of personhood, but doing forms an integral part of who we are. Being and doing is not mutually exclusive but mutually enriching, forming and transforming. In this sense of being and doing, personhood takes on the form of an (Klaasen 2017):

$[A]$ cting agent who is continuously formed and forming. Personhood is closer to the orthodox view of creation, namely that one is in a living process of formation and not a fixed finish product. (p. 5)

Theological motivations for personhood are also found in the creedal formulation of the God as Trinity. In a response to the Arian controversy, the Cappadocian Fathers (Basil the Great, bishop of Caesarea 329-379, Gregory of Nyssa 335394 and Gregory of Nazianzus 329-390) formulated the conceptualisation of the Trinity as three hypostases. This means that God is not three from a mathematical point of view or from a power relational perspective. God is three in one as hypostases, meaning that God is distinguished as Father, Son and Holy Spirit in a single being in communion. This can be symbolically represented by `human reproduction and breath and procession'. One can also speak of the 'universal and its particulars'. In this formulation of God as Trinity, persons are all relations but 'possess stories, actions and speech which make them agents' with responsiveness. This formulation also affirmed the persona and its essential rationality (Klaasen 2013:186-187).

The perichoretic paradigm of John of Damascus is 'the reciprocal giving and receiving of free communion between Father, Son and Spirit' (Speidell 1994:283-284). Persons exist not by themselves but in voluntary invitation in relation with the other (Speidell 1994:285). Person here refers to interdependence and not the independence that is associated with individual. Whilst an individual has reason as normative for personhood, a person relates to others in his or her quest for personhood. Relating person to God, one can deduce that God is not 'impersonal, mechanistic' but in voluntary relations between Father, Son and Holy Spirit (Speidell 1994:285).

The contribution that theology brings to the discourse of personhood and community development is the convergence that perceived opposites in African philosophy's notions of personhood propagates. The tension between the individual and community, processual and forming, moderate community and radical community, and identity and person arises from the insistence of normativity, which leads to antagonisms. The tension also arises out of the domination, on the one hand, of individual over community (Gyekye) or community over individual (Menkiti), and the attempt to pillarilisation (Molefe).

Relational theology comprises creative tension and not an either/or agenda. Personhood is about the principles such as relationships, interdependence, vocational and being, as well as attributes such as responsive, formative, complexity and capacity. Perceived opposites converge at personhood.

Relational theology propagates an ecclesial community that keeps in creative tension difference in such a way that persons are not separated. Persons are in a forming and transforming relationship that shapes and reshapes the fixed mechanistic self of the Enlightenment into a dynamic and fluid person that expands and transcends the boundaries beyond its enclavement. Difference becomes a moment of intuition to transcend the fixity of the similar.

\section{Markers of personhood for community development}

Personhood assumes that vocation evokes the potential of self and other. There is a convergence of being and doing. Who we are has as much to do with our being as with our doing. In other words, our personhood is interconnected with our vocation. Unlike the exclusivity of identity as substantial matters, such as religion, culture, social and political factors, for Steve de Gruchy, identity is inextricably connected with vocation. He claims that (De Gruchy 2015):

To recover a theological vision of vocation, my sense is that we need to move beyond an isolated focus on identity, which has tended to dominate African theology in the past while, and seek to intergrade issues of identity with a focus on agency. (p. 69)

De Gruchy (2015) draws on Sen's notion of agency and asserts that:

Sen recognises, like Freire, that if agency means anything then it is not just a question of mindless action, but also of a contribution at the level of theory to 'value and priorities' so that the preferences for political, social and economic life can be shaped by all citizens, including the poor, and not just the dominant elites. (p. 74)

Vocation is embedded in taking responsibility for creation, which includes both the living and non-living. Vocation has to do with taking responsibility and building the capacity of the constructing other. Personhood is interdependent. People have different skills, abilities, gifts and talents. Persons can unlock the potential to become and transcend the limitations of Sen's choices and Korten's social development. Whether it is the rich or poor, skilled or unskilled, each has a vocation that is entangled in who they are. Vocation goes beyond expanding choices (Sen) and compels a person to make the choice to engage in the development of the self and the constructing other through community development.

Person and the community are not separated, but through reciprocity they form a co-partnership for effective community development. If the person grows, the community grows. Unlike the prevailing African philosophical notion of the dominance of community over the individual, in Tutu's understanding of personhood the individual and community are interdependent. Whilst personhood presupposes community, individuality is relational and (Koopman 2003): 
When Ubuntu is evaluated in terms of Christian Trinitarian thinking it becomes clear that an emphasis on relationship that nullifies the uniqueness and integrity of the individual is strongly objected. In the same way the nullifying of individual freedom is objected. The notion of perichoresis, for instance, implies a nonforced cooperation and solidarity between the Persons of the Trinity. (pp. 199-200)

The kind of relationship that perichoresis implies is not a one-way or dominant relationship that is normative in the widespread African notion of Ubuntu, rather it is one that is rooted in a dialogical kind of relationship (Klaasen 2017):

It includes both relation and distance. The relationship is such that participation does not usurp the uniqueness of the other and does not result in the antagonistic distant other. Instead, relationship here refers to the mutually enriching interaction of each unique person in the shared life of the community. (p. 40)

A major limitation of the community development models has been the one way receiver-giver systemic nature. The receiver is the passive role player whilst the giver is the active provider. Within Christian anthropology, the receiver possesses skills and properties that are particular and indispensable to community development. The giver, on the other hand, has specialised skills that are of equal necessity for transformative community development.

Koopman (2003) avers that:

From within Christianity it can be argued that where the dependence on others, specifically God, is seen as essential part of humanity there the fear for receiving disappear. There people recognise that the value of human beings does not only reside in what we can give, but more so in that we receive. There the protestant confession of justification by grace, of salvation without merit or any contribution from the side of the human being, is cherished. And where we learn to receive, we learn to claim the god given rights of others and may I even say ourselves. (pp. 203-204)

The receiver-giver theological principle is illustrated by Goulet in the following two claims she makes. She demonstrates the complexity of human development when she refers to the response of the Swiss philosopher Jeanne Hersch to the French political philosopher's assertion that society would place a different meaning on material prosperity even if material deprivation would be universally abrogated and George Kennan's assertion that developed countries can do little more than providing underdeveloped countries with possible choices (Goulet 1995):

Hersch feared that exaggerated material development could render people powerless to make profound value choices because they will have become 'distracted' (in Pascal's sense, 'diverted') by the abundance of goods and activities from properly human considerations. (p. 49)

She further asserts that there are four pathways to development, namely: growth, redistribution, basic human needs and development from tradition. The latter is a radical diversion from the first three and is rooted in the tradition of the developing countries and not the developed ones (Goulet 1995):

For the defenders of tradition as the values matrix of modernity, the goals of a form of development suited to a particular society should be sought from within the latent dynamism of that society's value system - its traditional beliefs, its meaning system, its institutions, networks of solidarity, and popular practices.... Not that modern ideas, behaviour, and technology are to be repudiated on principle, but rather that they must be critically examined in instrumental fashion to determine whether or not they can contribute to the sound human development of individuals and communities. (p. 88)

\section{Conclusion}

Community development has shifted from one-way development to the role of developing communities for effective and meaningful community development. This shift was brought about by the investigation of an international research group that combined the three approaches of Use Your Talents, CABLE and Seeking Conviviality into CODE. At their most recent international gathering, this research group designed a three-pronged approach that includes conceptual issues, empirical research, as well as training and education.

This contribution is a contribution within the conceptual framework of community development from a theological perspective. Theological anthropology engaged the notions of personhood and Ubuntu as important concepts for community development. Community and development were combined as two entangled concepts and a brief definition of community development was formulated.

The complexity of the notions of personhood within African scholarship both contributes to a greater conceptualisation of the term and highlights its limitations. A Christian perspective of personhood and community, as used by Tutu, enriches the two terms. A Christian anthropological perspective of personhood adds three markers towards transforming community development, which include the creative tension between being and doing, individual and community, and receiver and giver.

\section{Acknowledgements Competing interests}

The author declares that he has no financial or personal relationships that may have inappropriately influenced him in writing this article.

\section{Author's contributions}

J.S.K. is the sole author of this research article.

\section{Ethical considerations}

This article followed all ethical standards for a research without direct contact with human or animal subjects. 


\section{Funding information}

This research received no specific grant from any funding agency in the public, commercial or not-for-profit sectors.

\section{Data availability statement}

Data sharing is not applicable to this article as no new data were created or analysed in this study.

\section{Disclaimer}

The views and opinions expressed in this article are those of the author and do not necessarily reflect the official policy or position of any affiliated agency of the author.

\section{References}

Alkire, S., 2010, Report of Oxford Human Development report, Oxford poverty and human development Initiative, Oxford.

Battle, M., 1997, Reconciliation: The Ubuntu theology of Desmond Tutu, The Pilgrim Press, Cleveland, $\mathrm{OH}$.

Bosch, D.J., 1991, Transforming mission: Paradigm shifts in theology of mission, Orbis Books, New York, NY.

Collins English Dictionary, n.d., Development, viewed 11 December 2019, from https://www.collinsdictionary.com/dictionary/english/development

Conradie, E., 2016, 'Why cannot the term development just be dropped altogether? Some reflections on the concept of maturation as alternative to development discourse', HTS Teologiese Studies/Theological Studies 72(4), 1-11. https://doi. org/10.4102/hts.v72i 4.3415
De Gruchy, J., 2006, Being human: Confessions of a Christian humanist, SCM Press, London.

De Gruchy, S., 2015, 'Of agency, assets and appreciation: Seeking some commonalities between theology and development', in B.G. Haddad (ed.), Keeping body and soul together: Reflections by Steve De Gruchy on theology and development, pp. 6687, Cluster Publications, Pietermaritzburg.

Dietrich, S., 2017, Summary report of the CODE Forum: Community, participation and power, minutes from a meeting, Oslo, 19-20 October.

Eze, M.O., 2010, Intellectual history in contemporary South Africa, Pallgrave MacMillan, New York.

Goulet, D., 1995, Development ethics: A guide to theory and practice, Apex Press, New York.

Gyekye, K., 1997, Tradition and modernity: Philosophical reflections on the African experience, Oxford University Press, Oxford.

Klaasen, J., 2013, 'The interplay between theology and development: How theology can be related to development in post-modern society', Missionalia 41(2), 65-81. https://doi.org/10.7832/41-2-13

Klaasen, J., 2017, 'The role of personhood in development: An African perspective on development in South Africa', Missionalia 45(1), 29-44.

Koopman, N., 2003, 'Trinitarian anthropology, Ubuntu and human rights', in K. Sporre \& H.R. Botman (eds.), Building a human rights culture: South African and Swedish perspectives, pp. 194-207, Stralins, Falun.

Majeed, H.M., 2017, 'The nexus between "Person," personhood, and community in Kwame Gyekye's philosophy', Unizik Journal of Arts and Humanities (UJAH) 18(3), 26-45. https://doi.org/10.4314/ujah.v18i3.2

Merriam Webster Dictionary, n.d., Organism, viewed 25 March 2019, from https:// www. merriam-webster.com/dictionary/organism 20/02

Molefe, M., 2017, 'Personhood and rights in an African tradition', South African Journal of Political Studies 45(2), 1-15. https://doi.org/10.1080/02589346.2017.1 339176

Speidell, T.H., 1994, 'A Trinitarian ontology of persons in society', Scottish Journal of Theology 47(3), 283-300. https://doi.org/10.1017/\$0036930600046202

Springett, D. \& Redclift, M., 2015, 'Sustainable development: History and evolution of the concept', in M. Redclift \& D. Springett (eds.), n.p., Routledge International handbook of sustainable development, Routledge, London.

Tutu, D., 2004, God has a dream: A vision of hope for our time, Random House, London. 